\title{
POLA INTERAKSI MASYARAKAT ARAB - SUNDA DI KABUPATEN PURWAKARTA
}

\author{
Oleh Nina Merlina \\ Balai Pelestarian Sejarah dan Nilai Tradisional Bandung \\ Jln. Cinambo No. 136 Ujungberung Bandung \\ Email: ninamerlina@ymail.com
}

\begin{abstract}
Abstrak
Interaksi sosial sebagai faktor utama dalam kehidupan sosial, didasarkan pada komunikasi. Proses interaksi adalah suatu proses yang mengharuskan adanya suatu kerja sama antara dua atau lebih kelompok. Kondisi itu terjadi dalam proses asosiatif antara masyarakat Arab dan Sunda di Kabupaten Purwakarta. Interaksi sosial antara kedua etnis tersebut sangat mewarnai kehidupan sosial di daerah Purwakarta.
\end{abstract}

Kata kunci: interaksi sosial, komunikasi, Arab-Sunda.

\section{Abstract}

Social interaction is a primary factor in social life, based on communications. The main interaction process is an associative process. It is a process that requires teamwork between two people or more. This condition occurs in associative process between the Arabian people and Sundanese people in Purwakarta. The social interaction between two ethnics greatly affects the social life in Purwakarta.

Keywords: Social interaction, communication, Arab-Sundanese.

\section{A. Pendahuluan}

Bangsa Indonesia merupakan bangsa majemuk. Kemajemukan itu ditandai oleh adanya suku-suku bangsa atau etnis, yang masing-masing mempunyai cara hidup atau kebudayaan yang berlaku dalam masyarakatnya, sehingga mencerminkan adanya perbedaan dan pemisahan antara suku bangsa yang satu dengan suku bangsa yang lain. Oleh karena itu, setiap bangsa yang multi etnis, termasuk Indonesia, berpotensi menghadapi masalah perbedaan, persaingan, dan tidak jarang pertikaian antaretnis. $\mathrm{Hal}$ ini disebabkan, etnis merupakan fenomena biologis yang berdampak kultural, sosial, ekonomi, dan politik. Walaupun fenomena etnis secara internal bisa berfungsi integratif, secara eksternal berpotensi konflik.

Berdasarkan ciri-ciri utama biologisnya, umat manusia dikelompokkan ke dalam berbagai ras. Bila ras dikaitkan dengan kebudayaan, maka terbentuklah kelompok etnik. Menurutn Barth, yang dimaksud dengan kelompok etnik adalah suatu populasi yang secara biologis mampu berkembang biak dan bertahan, mempunyai nilai-nilai budaya yang sama dan sadar akan kebersamaan dalam suatu 
bentuk budaya, membentuk jaringan komunikasi dan interaksi sendiri, menentukan sendiri ciri kelompoknya, yang diterima oleh kelompok lain dan dapat dibedakan dari populasi lain. Untuk membedakannya dengan ras, maka suatu etnik harus mempunyai homeland atau tanah leluhur. Oleh karena itu, dari suatu ras yang sama bisa terbentuk berbagai etnik.

Pada dasarnya, setiap kelompok kebudayaan memiliki sifat etnosentrisme. Perbedaan yang ada di antara kelompok kebudayaan di Indonesia pada dasarnya disebabkan oleh perbedaan sejarah perkembangan kebudayaan masyarakat dan juga oleh penyesuaian diri terhadap kebudayaan asing dan agama yang sudah masuk sejak masa lampau. Namun demikian, perbedaan-perbedaan tersebut tetap dapat mengutamakan kita sebagai suatu bangsa, yakni bangsa Indonesia dengan melalui suatu perjuangan yang berat menjadi suatu bangsa yang merdeka dan berdaulat.

Biasanya keanekaragaman suku bangsa dan bahasa merupakan awal kerawanan atau disintegrasi suatu bangsa, apabila tidak ada ideologi sebagai pengikat persatuan dan kesatuan bangsa yang dapat diterima oleh setiap suku bangsa di Indonesia. Sebagai makhluk sosial, manusia memiliki akal yang memungkinkan dirinya dapat berkomunikasi dengan manusia lainnya, dan terciptalah kebudayaan. Dengan kata lain, hubungan manusia dengan lingkungannya dijembatani oleh kebudayaan, yang merupakan pola bagi kehidupan manusia. Adanya kebiasaan atau kelakuan berpola dalam masyarakat tertentu merupakan salah satu cara penyesuaian masyarakat itu terhadap lingkungannya. Oleh karena itu, setiap masyarakat mempunyai pola kebudayaan yang khas dan berbeda dengan masyarakat lain. Seperti halnya pada masyarakat Purwakarta yang berpenduduk campuran, dalam arti penduduknya lebih dari satu etnis, di antaranya adalah etnis Arab dan Sunda.

Pengaruh kontak budaya, antara etnis Arab dan Sunda, merupakan faktor yang kuat dalam membentuk perkembangan dan problemnya. Berdasarkan uraian di atas, permasalahan yang dapat ditarik dalam penelitian ini adalah sebagai berikut: a) Bagaimanakah pola interaksi sosial kedua etnik tersebut?; b) Akibat-akibat sosial apa yang muncul dari hubungan sosial tersebut?; c) Bagaimanakah etnis Sunda mengkonstruksi dan memposisikan kelompok etnis Arab?

Adapun tujuan dari penelitian ini adalah untuk memahami secara lebih mendalam dan menyeluruh fenomena interaksi sosial antara etnis Arab dengan Sunda di Purwakarta. Adapun materi dalam penelitian ini adalah aspek kebudayaan yang berkaitan dengan sistem dan nilai kemasyarakatan yang berlaku pada masyarakat Pasar Rebo, Purwakarta. Ruang lingkup wilayah penelitian adalah Kampung Arab, Kelurahan Nagrikidul, Kecamatan Purwakarta, Kabupaten Purwakarta. Alasan pemilihan lokasi penelitian adalah, karena lokasi ini memiliki sejarah sosial yang cukup menarik yang berhubungan dengan interaksi sosial etnik Arab dengan etnik Sunda.

Penelitian ini merupakan penelitian yang bersifat deskriptif dengan tujuan menggambarkan gejala-gejala sosial yang tampak. Metode yang digunakan dalam penelitian ini adalah metode deskriptif dengan penelaahan data yang bersifat kualitatif, yaitu suatu cara yang digunakan untuk menyelidiki dan memecahkan masalah yang tidak terbatas pada pengumpulan dan penyusunan sampai pada kesimpulan yang didasarkan atas penelitian (Surakhmad, 1982:19).

Teknik pengumpulan data yang digunakan dalam penelitian ini, antara 
lain adalah observasi atau pengamatan langsung di lapangan, kemudian wawancara dengan responden atau informan di daerah penelitian, serta studi pustaka yang terkait dengan masalah dan relevan dengan penelitian. Responden yang dimaksud ialah, masyarakat Sunda dan etnis Arab, yang tinggal di Pasar Rebo Purwakarta. Secara empirik, masyarakat Sunda merupakan mayoritas keturunan Sunda yang bertempat tinggal di lokasi penelitian.

\section{B. Bahasan}

Purwakarta merupakan salah satu kabupaten di Jawa Barat yang terdiri atas beberapa etnis, di antaranya adalah etnis Sunda sebagai pribumi dan etnis asing yaitu etnis Arab. Pada beberapa wilayah di Kabupaten Purwakarta, banyak ditemukan warga keturunan Arab, terutama di wilayah Pasar Rebo, Pasar Jumat, Simpang hingga mendekati Kampung Wanayasa. Oleh karena itu, tidak heran apabila daerah sekitar itu dijuluki Kampung Arab. Hal ini disebabkan hampir $80 \%$ penduduknya adalah keturunan Arab. Kontak budaya antara etnis Arab dengan etnis Sunda tidak dapat dihindari.

Kontak sosial dapat bersifat positif, apabila mengarah pada suatu kerjasama (cooperation). Kontak sosial juga bisa bersifat negatif, apabila mengarah pada suatu pertentangan (conflict), atau bahkan sama sekali tidak menghasilkan suatu interaksi.

\section{Interaksi dalam Komunitas Kampung}

Etnis Arab relatif dominan di beberapa wilayah Pasar Rebo, Kelurahan Nagrikidul tersebut. Walaupun kelompok etnis Arab termasuk penduduk atau warga yang dominan di wilayah Kelurahan Nagrikidul, namun posisi atau kedudukannya sama, tidak ada keistimewaan. Dalam arti, etnis Arab tersebut mendapat perlakuan yang sama dengan etnis Sunda, sebagai penduduk pribumi.

\section{Gambar 1}

Warga keturunan Arab sedang berinteraksi dengan warga pribumi.

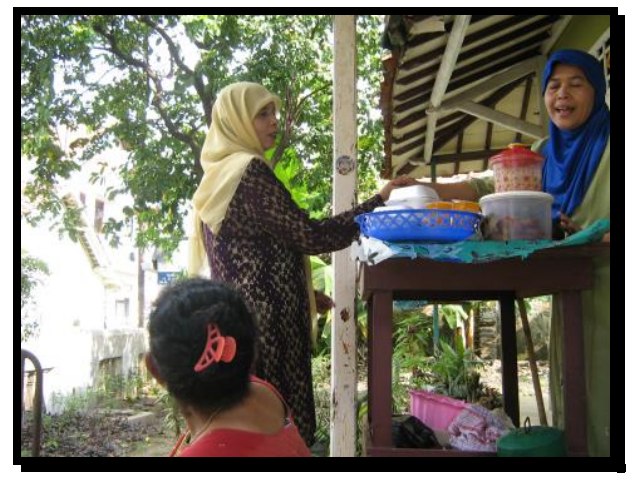

Sumber: Data penelitian 2008

Dalam kegiatan yang ada kaitannya dengan kepemerintahan, dalam hal ini pihak kelurahan, beberapa tokoh Arab ikut mendukung. Hal itu terlihat dalam keterlibatannya mengikuti rapat minggon atau mingguan yang diselenggarakan oleh pihak pemerintahan. Mereka (warga Arab) juga terdorong untuk ikut membangun daerahnya, bersama-sama dengan warga lainnya.

Warga Arab yang tinggal di wilayah Kelurahan Nagrikidul tidak merasa menjadi warga asing, mereka pun tidak mau disebut sebagai orang Arab, karena bagi mereka dengan sebutan itu, mereka dianggap sebagai warga asing. Bagi mereka, yang dimaksud dengan orang Arab adalah mereka yang lahir dan tinggal di Negara Arab. Warga Arab Purwakarta lebih senang disebut dan bahkan menyebut dirinya sebagai warga keturunan. 


\section{Gambar 2}

Seorang warga keturunan Arab yang menjadi pengurus RT.

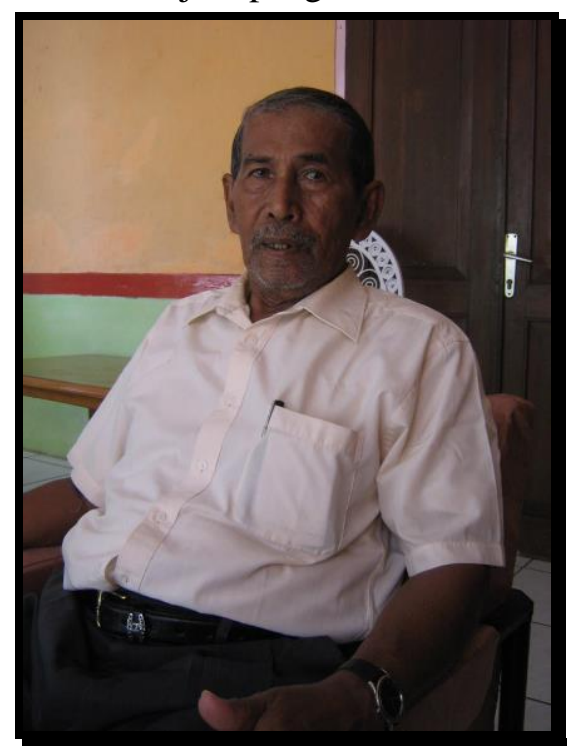

Sumber: Data Penelitian 2008

Mereka menamakan dirinya sebagai warga keturunan karena merupakan hasil perkawinan campuran dengan warga pribumi, dan tinggal di wilayah, dimana mereka menikah: "Kami lain dengan bangsa Cina yang datang ke Indonesia. Bangsa Cina kebanyakan menikah dengan bangsa Cina-nya sendiri, sedangkan bangsa kami menikah dengan pribumi. Jarang sekali bangsa Cina yang menikah dengan penduduk asli atau pribumi", begitulah penuturan seorang warga keturunan, yang tinggal di wilayah Kelurahan Nagrikidul, Kecamatan Purwakarta.

Penduduk Arab dengan pribumi membaur begitu saja, tidak ada perbedaan ras yang menyebabkan tidak bersatunya orang Arab dengan pribumi. Sebaliknya, warga Arab dengan pribumi sangat kompak. Hal ini disebabkan, mereka merasa saudara seibu. Orangorang Arab yang mayoritas datang dari Hadraamaut Yaman Selatan tidak membawa istri atau keluarga, ketika datang ke Purwakarta.
Gambar 3

Anak-anak bermain tidak terbatas etnis.

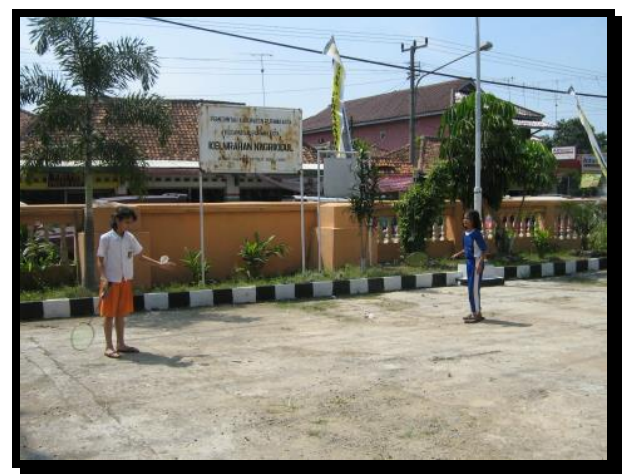

Sumber: Data Penelitian 2008

Dalam menjalin silaturahmi, di antara mereka, warga keturunan dengan pribumi mengikuti kegiatan-kegiatan sosial yang ada di wilayahnya, seperti posyandu, arisan. Arisan merupakan suatu kegiatan menarik atau kegiatan mengumpulkan uang dalam jumlah tertentu dari orang-orang yang telah ditentukan pula jumlahnya. Uang yang terkumpul akan diberikan kepada salah satu anggota peserta arisan yang berhasil keluar sebagai pemenang. Pada umumnya, kelompok arisan ini dilakukan oleh kaum perempuan, dan jarang sekali dilaksanakan oleh kaum pria.

\section{Interaksi dalam Kegiatan Keagamaan}

Masyarakat Purwakarta, khususnya yang berdomisili di wilayah Kelurahan Nagrikidul sangat agamis. Hal itu terlihat dari kegiatan sehari-hari, terutama dalam kegiatan keagamaan. Kegiatan keagamaan yang ada dalam kehidupan masyarakat Kelurahan Nagrikidul sangat menonjol, terutama di lingkungan Pasar Rebo, hal ini terlihat dengan banyaknya kelompok pengajian.

Pengajian yang diadakan di lingkungan Pasar Rebo merupakan pengajian yang terdiri atas kelompok pengajian wanita dan kelompok pengajian laki-laki. Adapun waktu yang 
disediakan untuk pengajian adalah siang hari untuk wanita, dan malam hari untuk laki-laki atau bapak-bapak.

\section{Gambar 4}

Ibu-ibu sangat berantusias mengikuti pengajian.

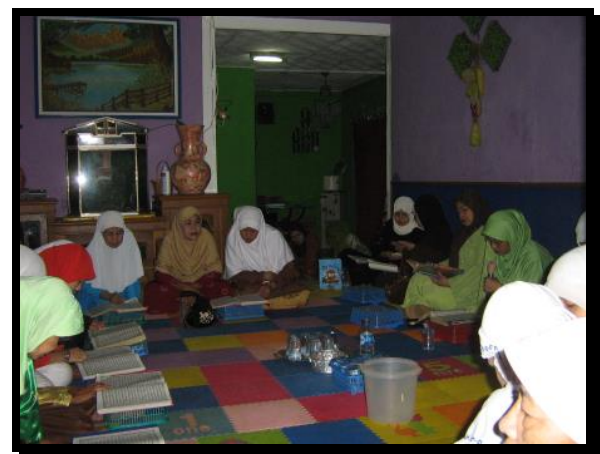

Sumber: Data Penelitian 2008

Kelompok pengajian yang dilaksanakan oleh kaum bapak-bapak diselenggarakan pada malam hari, yakni pada malam Rabu dan Sabtu. Pengajian untuk bapak-bapak dilaksanakan di Mesjid. Materi yang disampaikan pada kelompok pengajian ini, adalah tentang Sejarah Islam dan Tafsir Al Quran. Sejarah Islam disampaikan pada malam Rabu oleh Ustadz Salim Assegaf. Adapun tafsir Al Quran disampaikan pada malam Sabtu. Tafsir Al Quran disampaikan oleh Drs. Abdullah Jobban.

Masyarakat atau warga Pasar Rebo sangat antusias dengan pengajian yang diselenggarakan di lingkungannya. Hal ini terlihat dengan banyaknya pengunjung dalam setiap pertemuan atau pengajian, lebih kurang ada sekitar empat ratus orang yang datang dalam satu kali pertemuan, terutama kelompok pengajian yang diselenggarakan untuk kaum bapakbapak. Sebagai pencerahan dalam penerimaan ilmu agama, maka setiap bulan didatangkan penceramah dari luar, biasanya yang mengisi materinya adalah Habib Husen.

\section{Gambar 5}

Mengkaji dan belajar Al Quran adalah salah satu materi pengajian.

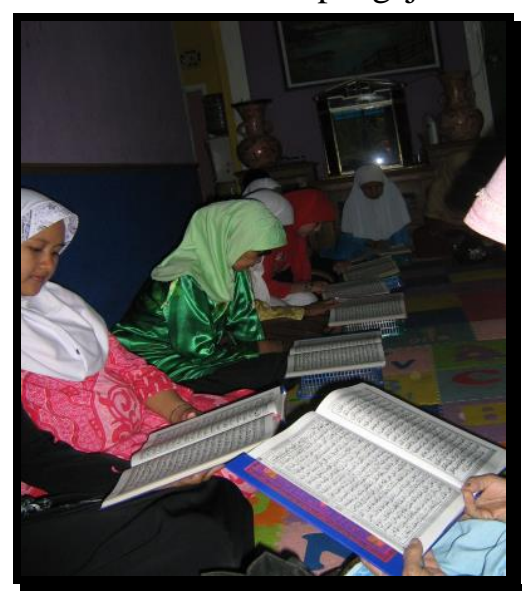

Sumber: Data Penelitian 2008

Kegiatan sosial yang berkaitan dengan keagamaan di lingkungan Pasar Rebo banyak sekali, terutama pada harihari tertentu pada Bulan Hijriyah, yakni pada hari-hari besar Islam, misalnya pada Bulan Muharram, Ramadhan, dan Bulan Syawal. Bulan-bulan tersebut, merupakan kesempatan untuk meningkatkan ibadah. Pada bulan-bulan tersebut, sebagian dari mereka terutama warga keturunan memberikan sodaqoh atau infak kepada mereka yang tidak mampu dan layak diberi. Hal ini sudah menjadi kebiasaan bagi warga keturunan dalam rangka melaksanakan silaturahmi dengan warga "pribumi" - dalam hal ini etnis Sunda, terutama dalam bulan Muharram. Pada bulan tersebut, khususnya pada tanggal 10 Muharram, setiap tahun secara rutin warga keturunan membagi-bagikan beras kepada warga pribumi. Jumlah beras yang dibagikan lebih kurang sebanyak 3 sampai $5 \mathrm{~kg}$ per keluarga. Beras tersebut ditampung di tempat seseorang yang dianggap tokoh oleh masyarakat setempat. 


\section{Gambar 6}

Warga keturunan Arab dan pribumi berbaur dalam kelompok pengajian.

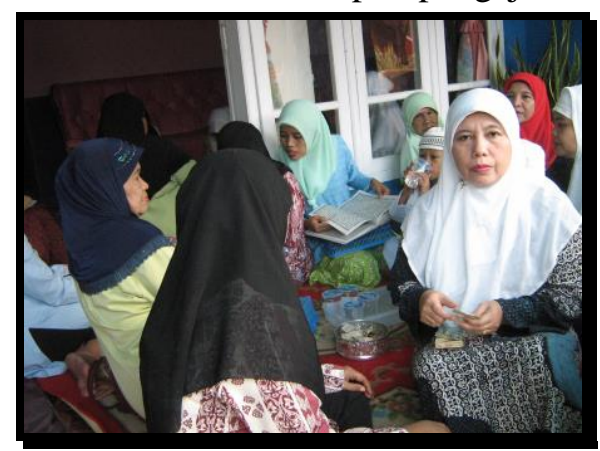

Sumber: Data Penelitian 2008

Sumbangan atau infak ini tidak dipaksakan, tapi sudah menjadi kesadaran bagi warga keturunan dan warga lainnya yang merasa mampu, bahkan menjadi suatu kewajiban bagi mereka yang mampu. Kegiatan lain yang dilakukan oleh warga keturunan, selain membagi-bagikan beras kepada warga, dalam bulan ini juga banyak kegiatankegiatan yang diistimewakan oleh warga keturunan tersebut.

\section{Gambar 7}

Ustadz Salim Assegaf, tokoh masyarakat.

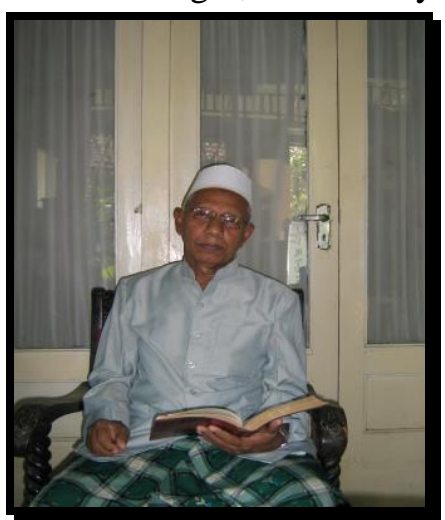

Sumber: Data Penelitian 2008

Pemberian keistimewaan tersebut terjadi juga di dalam lingkungan keluarga. Misalnya dalam satu kehidupan keluarga, yang biasanya makan tidak begitu istimewa, pada saat itu lebih istimewa. Contoh lain, pemberian jajan kepada anak-anak juga ditingkatkan menjadi dua kali lipat. Alasan mereka mengistimewakan bulan ini, karena mereka beranggapan bahwa berdasarkan sejarahnya, pada bulan ini banyak peristiwa besar terjadi.

Hari-hari besar lain yang dianggap sangat istimewa adalah pada waktu Bulan Ramadhan. Bulan ini disemarakkan dengan kegiatan ibadah, di antaranya adalah sodaqah dan shalat berjamaah di masjid. Biasanya yang melakukan shalat berjamaah di masjid adalah laki-laki, hal ini dilakukan dengan rutin. Namun pada Bulan Ramadhan, banyak juga kaum wanita yang melaksanakan shalat berjamaah di masjid terutama shalat malam. Sudah menjadi kelaziman, apabila datang bulan suci Ramadhan orang berduyun-duyun, baik laki-laki maupun perempuan, anak-anak maupun remaja dan orang tua untuk shalat berjamaah di masjid.

Di Pasar Rebo terdapat sebuah Masjid besar, yakni Masjid Jami ArRoudlo. Masjid ini berdiri sejak masa kolonial Belanda, sekitar tahun 1940-an dan dibangun oleh seorang warga keturunan, seorang ulama terkenal, yakni Habib Muhamad bin Idrus Al Habsyi. Kini ia dimakamkan di kompleks pemakaman Sunan Ampel. Masjid ini dibangun dengan modal yang sangat minim, kemudian warga keturunan menyalurkan dan memberikan uangnya untuk membantu proses pembangunan masjid tersebut.

Masjid ini merupakan masjid tertua kedua, setelah Masjid Agung Purwakarta. Masjid Ar-Roudlo ini tidak pernah sepi dari kegiatan syiar agama maupun pembacaan $\mathrm{Al}$ Quran. Sehubungan dengan itu, masjid ini pun dinamakan Ar-Roudlo sejak awal, dengan tujuan agar Syiar dan tadarus terus dikumandangkan di masjid ini. Masjid inilah yang digunakan oleh warga dalam rangka meningkatkan ibadah, di 
antaranya adalah shalat berjamaah. Oleh karena itu, di masjid ini tidak pernah sepi dari kegiatan keagamaan.

\section{Gambar 8}

Masjid Jami Ar Roudlo (Masjid Arab) di Pasar Rebo, Kelurahan Nagrikidul.

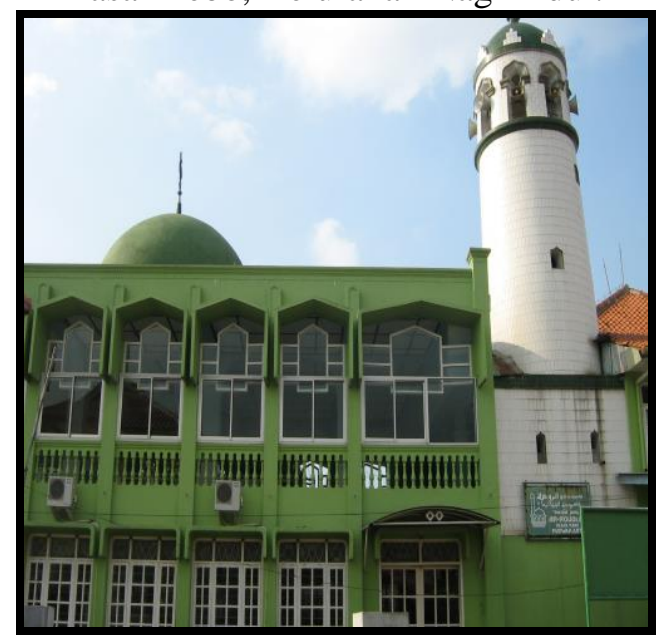

Sumber: Data Penelitian 2008

Selain tempat pengajian, masjid ini juga digunakan sebagai tempat pertemuan atau silaturahmi, terutama pada momen-momen yang benar-benar pas untuk melaksanakan silaturahmi, yakni pada saat menjelang Bulan Ramadhan. Menjelang Bulan Ramadhan, warga keturunan mengadakan acara silaturahmi di masjid Ar-Roudlo. Selain bersilaturahmi, warga keturunan juga menyampaikan ucapan selamat menjalankan ibadah puasa dan permohonan maaf kepada tetangga, baik tetangga sesama warga keturunan maupun tetangga pribumi, begitu juga kepada sanak saudaranya. Bagi warga keturunan, silaturahmi menjelang Bulan Ramadhan sangat penrting, karena Bulan Ramadhan merupakan Syahrul mubarak atau bulan penuh berkah.

Kegiatan silaturahmi lainnya yang dilaksanakan oleh warga Pasar Rebo adalah Halal bihalal. Halal bihalal digelar secara teratur, khusus laki-laki di hari kedua, perempuan di hari ketiga, dan ada juga halal bihalal khusus untuk wanita yang sudah tua. Dalam rangka merayakan hari raya Idul Fitri, masyarakat yang ada di lingkungan Pasar Rebo melaksanakannya sampai tiga kali bersalam-salaman.

Halalbihalal yang pertama dilaksanakan pada malam takbiran. Kedua, usai melaksanakan shalat Idul Fitri, dan ketiga, ketika halalbihalal yang dilaksanakan setelah hari $\mathrm{H}$ untuk lakilaki, dua hari setelah hari $\mathrm{H}$ untuk para perempuan muda, atau setelah puasa Syawal atau pada 8 Syawal untuk "wanita yang sudah tua". Jadi, perayaan lebaran lingkungan Pasar Rebo tidak selesai cukup dalam satu hari, melainkan selama satu minggu secara terus menerus, atau sampai tamat shaum syawal enam hari. Kebiasaan serta tradisi seperti ini sudah mereka jalani sejak lama, dan mereka akan tetap mempertahankannya.

\section{Interaksi dalam Kegiatan Pendidikan}

Pendidikan merupakan salah satu kebutuhan pokok dalam kehidupan manusia. Begitu pula bagi warga Pasar Rebo, Kelurahan Nagrikidul, Kecamatan Purwakarta, pendidikan merupakan kebutuhan utama. Sekolah merupakan salah satu sarana untuk memenuhi kebutuhan berpendidikan. Oleh karena itu, banyak warga Pasar Rebo yang memasukkan anak-anaknya ke sekolahsekolah yang dekat dengan lingkungannya. Sekolah yang ada di wilayah Kelurahan Nagrikidul, tidak ada kekhususan untuk etnis-etnis tertentu. Sekolah yang ada terbuka untuk umum. Oleh karena itu, semua warga berhak untuk mengenyam pendidikan di sekolah tersebut. Sekolah yang ada di lingkungan Pasar Rebo, Kelurahan Nagrikidul, Kecamatan Purwakarta ada yang 
merupakan sekolah umum, dan ada juga sekolah yang bersifat keagamaan.

Salah satu sekolah yang berdasarkan keagamaan, yani MAI. Semula MAI adalah singkatan dari Madrasah Arabiyah Islamiyah, yang didirikan pada tahun 1926 M oleh Mualim Said Joban dengan tujuan membentuk generasi Muslim yang berakhlakul karimah, berilmu, beramal, dan bertaqwa kepada Allah SWT. Di Madrasah ini pula dipersiapkan SDM yang siap pakai dalam menjawab tantangan zaman serta dinamika kehidupan masyarakat.

\section{Gambar 9}

MAI Purwakarta di Kelurahan Nagrikidul, Kecamatan Purwakarta.

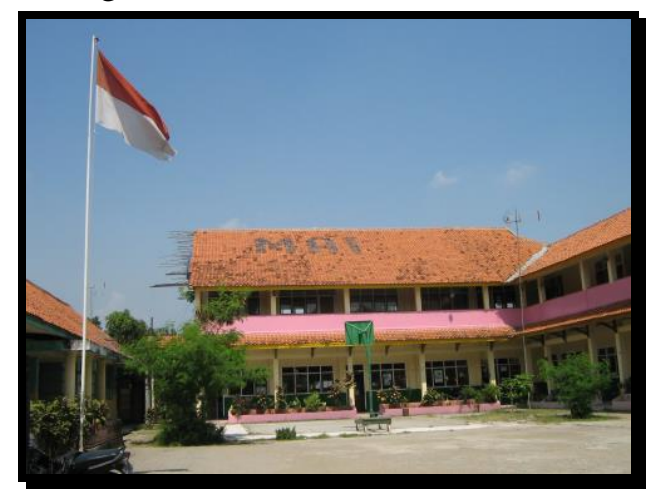

Sumber: Data Penelitian 2008

Sekolah tersebut bermula dari pengajian yang rutin dilaksanakan. Kemudian dihimpunlah anak-anak yang mengaji menjadi sebuah kelas. Lama kelamaan, madrasah ini berkembang hingga menghasilkan SDM yang berstatus di lingkungan masyarakat, baik itu di lingkungan pemerintahan, mulai dari lurah, camat sampai menjadi bupati, maupun lingkungan keagamaan, seperti mubaligh yang terkenal. MAI ini pernah mengalami zaman keemasan, yakni di bawah pimpinan Ustadz Muhammad Assegaf dan Mualim Joban.

Madrasah ini dalam perkembangannya mengalami perubahan status, dari Tsanawiyah enam tahun menjadi Tsanawiyah tiga tahun dan Aliyah tiga tahun. Sementara kurikulum yang digunakan masih kurikulum buatan sendiri (lokal), artinya masih belum menginduk pada kurikulum pemerintah (Departemen Agama).

Setelah berjalan lima tahun, Madrasah MAI Purwakarta berada di bawah bimbingan dan pembinaan Kandepag Kabupaten Purwakarta, statusnya meningkat dari "Terdaftar" menjadi "Diakui" berdasarkan Keputusan Kepala Kanwil Depag Provinsi Jawa Barat dan diperbaharui dengan SK Dirjen Binbag Islam. Statusnya terus meningkat, hingga Madrasah MAI Purwakarta bisa menyelenggarakan Ebta/Ebtanas sendiri sampai sekarang.

Saat ini, siswa/siswi MAI yang datang bukan saja dari Purwakarta, melainkan juga dari luar Purwakarta, seperti Jakarta, Bekasi, Kerawang, Bandung, Tasikmalaya, hingga ke Palembang. MAI yang pernah mengalami zaman keemasan di periode sebelumnya, sangat berharap kualitas SDM-nya dapat bertahan hingga kini dan di masa yang akan datang. Dengan banyaknya murid atau pelajar dari berbagai daerah, yang bermaksud untuk menuntut ilmu di sekolah tersebut, pembauran semakin jelas dan interaksi sosial antaretnis tidak bisa dihindari.

\section{Interaksi dalam Institusi Perkawinan Campuran}

Perkawinan merupakan salah satu tahapan dari rangkaian mata rantai lingkaran hidup manusia sejak lahir hingga meninggal. Dengan kata lain, jika sudah tiba waktunya, maka setiap orang akan memasuki tahapan tersebut. Perkawinan merupakan salah satu kegiatan sosial yang mempersatukan bukan hanya dua insan tetapi juga dua keluarga, bahkan dua kerabat yang sebelumnya tidak saling mengenal satu sama lain atau 
dengan kata lain dengan latar belakang sosial/budaya yang berbeda. Begitu pula dengan Lingkungan Pasar Rebo, yang dihuni oleh berbagai etnis, tidak menutup kemungkinan terjadi perkawinan antar dan intra etnis.

Tidak ada larangan bagi warga keturunan (Arab) Pasar Rebo untuk menikah dengan etnis lain, khususnya warga pribumi atau etnis Sunda. Mereka beranggapan bahwa masalah jodoh adalah mutlak kehendak Tuhan. Bagi masyarakat atau warga Pasar Rebo, perkawinan campuran yang dilaksanakan dengan etnis Sunda sudah menjadi hal yang biasa dan banyak terjadi. Orang Arab datang ke Indonesia tanpa istri. Oleh karena itu, banyak dari orang Arab yang mempersunting gadis setempat atau gadis pribumi, untuk dijadikan istri.

Sejak dari awal kedatangan ke daerah Pasar Rebo Purwakarta, turunan mereka ataupun orang Arab yang datang kemudian diajarkan bahwa orang pribumi adalah saudara seibu. Jadi, tidak ada yang namanya "orang Arab yang lebih baik dari orang pribumi. Kita semua sama, sejajar," tutur salah seorang tokoh Arab Pasar Rebo yang tidak mau disebutkan namanya. Uniknya, jika ada yang menikah orang kaya maupun orang yang tidak punya, acaranya sama meriahnya.

Lazimnya, warga keturunan yang melangsungkan akad pernikahan tidak seperti warga pribumi. Pada waktu akad nikah atau ijab qabul, si mempelai lakilaki yang melaksanakan akad tanpa didampingi mempelai wanita. Pada saat akad, mempelai wanita menunggu di dalam. Setelah akad selesai, barulah si mempelai laki-laki dibawa ke tempat pelaminan dan duduk bersanding dengan mempelai wanita.

Ada keunikan dalam upacara perkawinan warga keturunan, yakni adanya jadwal-jadwal khusus untuk para undangan yang menghadiri upacara tersebut. Jadwal tersebut adalah, undangan khusus untuk para orang tua khususnya keluarga besan, adalah pukul 10.00 sampai pukul 11.00. Setelah Dhuhur sampai pukul 15.00, khusus undangan untuk kerabat dekat laki-laki. Setelah kaum laki-laki, kemudian undangan untuk para gadis atau kaum muda, yakni dari mulai pukul 16.00 sampai malam. Tempat duduk untuk para undangan laki-laki dengan perempuan dipisahkan. Tata cara dalam upacara ini walaupun pada awalnya dilakukan oleh warga keturunan, namun bagi masyarakat yang tinggal di lingkungan Pasar Rebo ada juga yang mengikuti sistem seperti itu, walaupun tidak sama persis.

\section{Interaksi dalam Kegiatan Ekonomi}

Lingkungan Pasar Rebo merupakan pusat perdagangan. Sepanjang jalan merupakan tempat berjajarnya pertokoan dan di belakangnya, terdapat pasar tradisional. Sepanjang jalan raya terdapat toko-toko dengan jenis barang berbeda dari yang ada di pasar. Toko tersebut diusahakan oleh para pedagang dari berbagai etnis, terutama yang bertempat tinggal di sekitar daerah Pasar Rebo. Adapun etnis yang dominan yaitu etnis Arab dan Sunda. Mereka memiliki toko tersebut secara turun temurun, jarang sekali yang mengoperalihkan kepemilikan toko tersebut ke pihak lain yang berasal dari luar Pasar Rebo.

Pasar yang merupakan pusat keramaian yang ada di daerah Pasar Rebo adalah pasar tradisional, tempat jual beli/ berdagang dengan jenis dagangan yang sangat bervariasi, mulai dari hasil bumi, ternak dan perikanan sampai dengan barang pabrikan.

Pasar merupakan tempat bertemunya orang-orang dan tempat berlangsungnya transaksi jual beli. Lebih luas lagi, pasar adalah tempat terjadinya 
transaksi ekonomi bagi masyarakat dari berbagai kalangan. Oleh karena itu, untuk memenuhi kebutuhan hidup sehariharinya, masyarakat di sekitar Pasar Rebo, cukup berbelanja di pasar tradisional terdekat. Kebutuhan hidup tersebut bisa berupa sembilan kebutuhan pokok sehari-hari dan kebutuhan hidup lainnya, seperti pakaian, perhiasan, alatlat kebutuhan rumah tangga, perlengkapan rumah tinggal, dan lainlain.

\section{Gambar 10}

Salah seorang pedagang di Pasar Rebo.

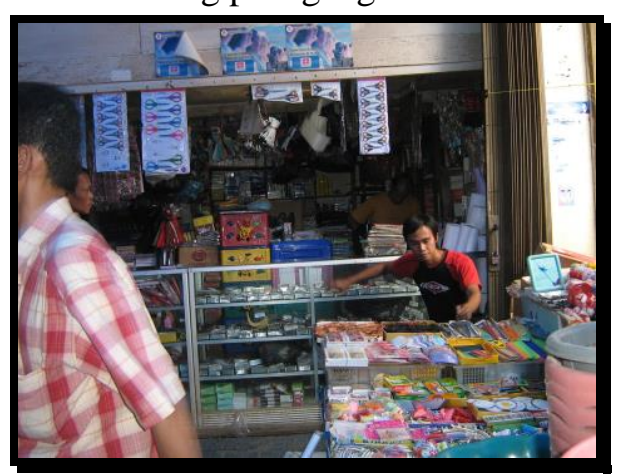

Sumber: Data Penelitian 2008

Tempat berjualan, baik itu berupa toko-toko maupun yang ada di dalam pasar, tidak terkonsentrasi atau tidak mengelompok secara etnik, melainkan saling berbaur dengan pedagang dari berbagai etnik. Kondisi demikian menyebabkan terjadinya interaksi di antara para pedagang pasar. Hubungan mereka menjadi sangat bebas, tidak terhalang lagi oleh perbedaan latar belakang keturunan atau daerah asal mereka. Komunikasi di antara mereka dengan pembeli sangat akrab, dengan bahasa pengantar, kadang bahasa Sunda, bahasa Indonesia, dan kadang bahasa Arab. Bahasa Arab yang digunakan adalah bahasa yang sudah umum dan dikenal oleh masyarakat Sunda, khususnya yang bermukim di derah Pasar Rebo.

\section{Gambar 11}

Seorang warga keturunan Arab berjualan di Pasar Rebo.

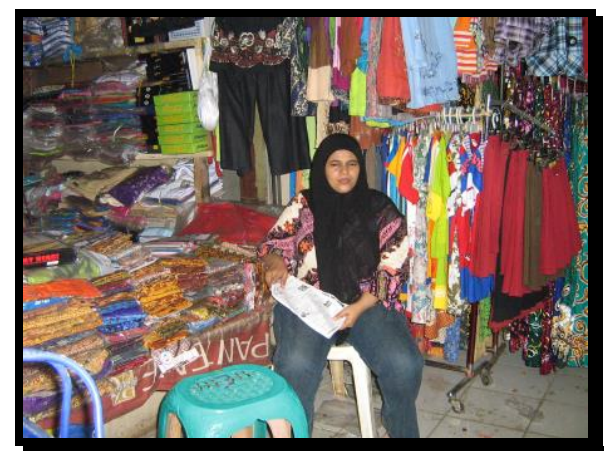

Sumber: Data Penelitian 2008

Barang-barang dagangan yang mereka pasarkan di Pasar Rebo tidak semuanya berasal dari lingkungan sediri, juga dari luar daerah. Untuk komoditi tertentu, mereka mendatangkan dari luar. Misalnya sepatu, mereka mendatangkan dari Bandung, khususnya dari Cibaduyut. Untuk pakaian, seperti baju muslim, mereka mendatangkan dari Soreang, Bandung. Adapun untuk pakaian dalam, kebanyakan mereka datangkan dari Jakarta. Dengan kata lain, untuk setiap komoditi tertentu, mereka sudah punya kontak dengan pemasok-pemasok. Istilah pemasok ini di kalangan para pedagang di Pasar Rebo dikenal dengan sebutan cepol. Para cepol ini datang seminggu sekali untuk memasok barang. Dengan demikian, keberlangsungan ekonomi berjalan dengan lancar. Persaingan dalam berdagang relatif kecil.

Bentuk kepedulian sosial antarpedagang tersebut tidak hanya terbatas pada sesamaetnis, tetapi juga antaretnis atau bagi semua warga yang bertempat tinggal di daerah Pasar Rebo. Terdapat anggapan di antara mereka, bahwa orang yang paling diharapkan bisa membantu dengan segera adalah orang yang ada di dekatnya atau tetangga. Oleh karena itu, sudah selayaknyalah saling menolong itu dengan tetangga terdekat terlebih dahulu. Hal ini sesuai dengan prinsip Islam yang mengatur hubungan antarsesama manusia, hubungan 
manusia dengan alam, dan hubungan manusia dengan Penciptanya, atau melakukan interaksi dan bersosialisasi dengan baik di lingkungan masyarakat.

\section{Interaksi Sosial di Tempat Umum}

Interaksi di tempat-tempat umum sangat memungkinkan terjadi di lingkungan Pasar Rebo, Kelurahan Nagrikidul. Hal ini disebabkan, tempat-tempat umum banyak dikunjungi orang-orang, seperti masjid, pasar, terminal, tempat-tempat berolah raga. Salah satu sarana yang menunjang dalam melaksanakan interaksi di lingkungan seperti tersebut di atas, adalah angkutan umum. Sarana angkutan umum yang ada di lingkungan Pasar Rebo, Kelurahan Nagrikidul adalah angkot, ojeg, juga becak. Angkot merupakan sarana transportasi yang dapat menghubungkan satu daerah ke daerah lain. Sebagian besar warga yang menjadi supir angkot adalah warga pribumi atau masyarakat Sunda, walaupun tidak memungkiri, ada juga warga keturunan yang menjadi supir angkot. Sarana transportasi lain yang dapat menjelajah wilayah sekitar pasar ke bagian pelosok adalah sepeda motor atau ojeg. Banyak warga yang memanfaatkan sarana tersebut, terutama warga yang tinggal daerah-daerah yang tidak dilalui angkot, sedangkan becak merupakan sarana angkutan umum yang digunakan untuk mengantar penumpang ke pelosok dengan jarak yang tidak begitu jauh.

\section{Gambar 11}

Suasana di terminal angkot / ojeg.

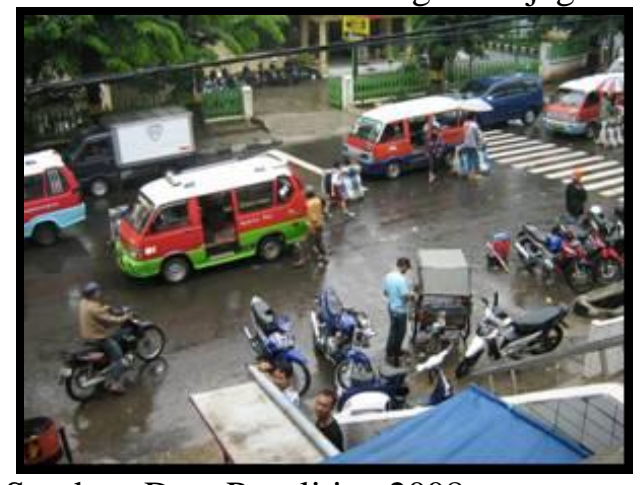

Sumber: Data Penelitian 2008
Lokasi yang dijadikan tempat mangkal supir angkot dan motor ojeg adalah terminal yang menyatu dengan pasar. Interaksi antara warga keturunan dengan etnis Sunda terjadi pula di terminal, pada saat angkot berhenti. Pengemudi angkot atau supir yang berasal dari etnis Sunda akan berkomunikasi dengan warga keturunan. Mendapatkan penumpang tentu tidaklah mudah, sehingga para supir angkot harus dengan sabar menunggu kedatangan orang-orang yang akan menaiki angkotnya.

\section{Penutup}

Komunikasi merupakan dasar dari eksistensi suatu masyarakat. Interaksi sosial sebagai faktor utama dalam kehidupan sosial, hubungan antarmanusia, ataupun relasi-relasi sosial ini didasarkan pada komunikasi. Interaksi sosial antaretnik (hubungan antaretnik) selalu dalam kerangka basic personality structure. Meskipun dalam kehidupan sehari-hari tetap mengacu pada kebudayaan etniknya, tetapi tidak menganggu komunikasi antaretnik. Hal itu dimungkinkan karena pada setiap etnik terdapat mekanisme yang mengatur hubungan sosial yang meliputi hubungan antarindividu, individu dengan kelompok, dan kelompok dengan kelompok. Dalam mekanisme itulah terdapat seperangkat nilai yang sama dalam setiap etnik. Nilai-nilai itu antara lain sikap hormat menghormati, ramah tamah, gotong royong, tenggang rasa, musyawarah untuk mufakat, rasa setia kawan, toleransi, saling memperhatikan, jujur, adil, dan bijaksana.

Interaksi sosial antara etnis Arab dengan etnis Sunda Pasar Rebo Purwakarta, sudah menjadi satu pola perilaku dan perilaku yang terpola. Dapat kita amati, sesuai dengan misi yang dibawa oleh kelompok etnis Arab saat memasuki daerah Purwakarta adalah untuk berdakwah, maka pola kehidupan 
keagamaan secara Islam sangat kental dan terasa mewarnai kehidupan masyarakat Pasar Rebo Purwakarta. Dalam berbagai kegiatan keagamaan, secara langsung maupun tidak langsung terjadi interaksi antara etnis Arab Keturunan dengan etnis Sunda.

Kegiatan atau peristiwa budaya yang paling dapat diamati adalah peristiwa perkawinan. Pada umumnya etnis Arab mempersunting perempuan Sunda. Sebagai pasangan hidup, pola perilaku sosial mereka langsung terbentuk dan terjadi dari percampuran adat Sunda dan etnis Arab. Dalam kehidupan keseharian, peristiwa-peristiwa dan upacara-upacara keagamaan sangat mewarnai masyarakat Pasar Rebo, terutama pada harihari besar keagamaan.

Akibat yang paling menonjol dan terasa dari kontak budaya atau kontak sosial antara etnik Arab dengan etnik Sunda adalah adanya pusat kegiatan ekonomi atau perdagangan, yakni tokotoko dan kios berdiri rapat di pinggir jalan raya dan pasar tradisional, sebagai tempat berdagang atau tempat transaksi jual beli bagi masyarakat Purwakarta. Pelaku ekonomi itu sendiri tidak hanya etnis Arab, tetapi berbaur menjadi satu dengan etnis lainnya, terutama etnis Sunda. Hal ini menunjukkan bahwa pasar tradisional merupakan basis kegiatan ekonomi yang tidak pernah mati. Dari Pasar Rebo inilah, denyut ekonomi Purwakarta menggeliat dan mewarnai kehidupan sehari-hari masyarakat Purwakarta.

Masyarakat Sunda Purwakarta memposisikan etnis Arab sebagai saudara, bahkan pasangan hidup bagi yang telah menjalani perkawinan campuran, antara etnis Arab dengan etnis Sunda. Sehingga terjadilah akulturasi kebudayaan yang melahirkan kebudayaan baru, berupa kebiasaan-kebiasaan baru yang mewarnai kehidupan keseharian masyarakat kedua etnik tersebut.

Dalam banyak hal, pola perilaku etnis Arab menjadi contoh dalam kehidupan bermasyarakat, terutama dalam perilaku hidup sebagai pemeluk agama Islam. Bagaimana cara berdagang atau berjual beli sampai pada mengelola ekonomi dalam kehidupan pasar atau berbisnis. Kemudian dalam masalah perkawinan, terjadi perkawinan campur antara etnis Sunda dengan etnis keturunan Arab. Menariknya, dalam acara pernikahan selalu diadakan secara meriah dengan tidak melihat perbedaan antara yang kaya dengan yang miskin, karena adanya budaya saling menolong dan membantu, termasuk dalam acara perkawinan.

Dalam hal pendidikan, juga terlihat adanya pembauran antaretnis di lingkungan Pasar Rebo Purwakarta. Oleh karena pendidikan tidak pandang bulu, siapa yang mampu, mereka yang berhak. Apalagi untuk sekarang ini, pemerintah mencanangkan pendidikan gratis.

Untuk memahami lebih dalam lagi mengenai pola interaksi sosial antara etnis Arab dengan etnis Sunda di Purwakarta, perlu ditindaklanjuti dengan kegiatan penelitian yang lebih mendalam. Kegiatan lebih khusus dapat dilakukan dengan pendataan atau pendokumentasian dari berbagi kegiatan atau peristiwa budaya yang secara rutin dilakukan oleh komunitas masyarakat Pasar Rebo.

\section{DAFTAR PUSTAKA}

Habib, Achmad. 2004.

Konflik Antaraetnik di Pedesaan. Yogyakarta: LKIS.

Ihromi, T.O. 1981.

Pokok-pokok Antropologi Budaya. Jakarta: Gramedia. 
J. Vredenbregt. 1983.

Metode dan Teknik Penelitian Masyarakat. Jakarta: Gramedia.

Koentjaraningrat. 1984.

Kebudayaan Mentalitas dan Pembangunan. Jakarta: Gramedia.

Sucipto, Toto et al. 1996.

Integrasi Nasional, dalam Hubungan Antarsuku Bangsa dan Sistem Nilai Budaya Nasional. Bandung: Pelita.
Soekanto, Soerjono. 1990.

Sosiologi Suatu Pengantar. Jakarta: Raja Gravindo Persada.

Sumarsono et al. 1998/1999.

Budaya Masyarakat Perbatasan. Jakarta: Bupara Nugraha.

Surakhmad, Winarno. 1982.

Penelitian Dasar Metode Teknis.

Bandung: Tarsito. 